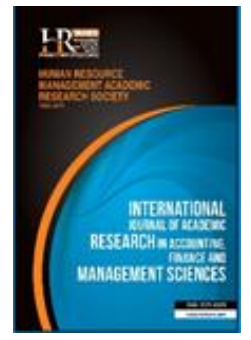

International Journal of Academic Research in Accounting, Finance and Management Sciences

Vol. 8, No.3, July 2018, pp. 45-52

E-ISSN: 2225-8329, P-ISSN: 2308-0337

(C) 2018 HRMARS

www.hrmars.com

To cite this article: Lădaru, G.-R., Marin, F., Diaconu, I.-I. (2018). The Situation of the Absorption of European Structural and Investment Funds in Romania during the Programming Period 2014-2020, International Journal of Academic Research in Accounting, Finance and Management Sciences 8 (3): 45-52.

\title{
The Situation of the Absorption of European Structural and Investment Funds in Romania during the Programming Period 2014-2020
}

\author{
Georgiana-Raluca LĂDARU ${ }^{1}$, Florian MARIN², Ionica-lonelia DIACONU ${ }^{3}$ \\ 1,2,3 The Bucharest University of Economic Studies, Romania, \\ ${ }^{1}$ E-mail: raluca.ladaru@eam.ase.ro, ${ }^{2}$ E-mail: marinflorian 21@yahoo.com, ${ }^{3}$ E-mail: ionelia d@yahoo.com
}

\begin{abstract}
One of the main advantages that the European Union's membership provides is European funds. Cohesion Policy or the Common Agricultural Policy are policies that regulate the organization of European structural funds and investment funds within a programming period. This article aims to inventory the European strategic and programming framework that regulates the absorption of European structural and investment funds at European level, the situation and allocations of the established operational programs, as well as the absorption dynamics at the level of the operational program in Romania. The need for a significant absorption process proves to be imperative for Romania in the conditions in which the tensions affecting the European project, both inside and outside, prove to be more and more accentuated. Identifying the absorption dynamics 4 years after the start of the programming period is likely to illustrate an image of Romania's performance in this process as well as to provide a set of future steps to streamline the absorption process.

Key words European structural fund, investment fund, absorption of European fund, programming period 2014-2020

\begin{tabular}{|c|c|c|}
\hline Received: & 25 Jul 2018 & (C) The Authors 2018 \\
\hline Revised: & 12 Aug 2018 & Published by Human Resource Management Academic Research Society (www.hrmars.com) \\
\hline $\begin{array}{l}\text { Accepted: } \\
\text { Published Online: }\end{array}$ & $\begin{array}{l}22 \text { Aug } 2018 \\
28 \text { Aug } 2018\end{array}$ & $\begin{array}{l}\text { This article is published under the Creative Commons Attribution (CC BY } 4.0 \text { ) license. Anyone may } \\
\text { reproduce, distribute, translate and create derivative works of this article (for both commercial and non- } \\
\text { commercial purposes), subject to full attribution to the original publication and authors. The full terms of } \\
\text { this license may be seen at: http://creativecommons.org/licences/by/4.0/legalcode }\end{array}$ \\
\hline
\end{tabular}
\end{abstract}

\section{Introduction}

In a context in which the reform of the European Union is called for by an increasing number of Member States, where we are discussing a two-speed European Union, Member States must make the most of the instruments they have in place to ensure an increase the quality of life and the generation of economic growth. However, differences between East and West within the European Union have increased; inequality and poor access to welfare are elements that have affected public policies promoted by the European Commission. It is not to be forgotten the growing geopolitical context, especially Russia and the USA. In this framework, the European Union must find its optimal economic development and marry on economic and social cohesion to progress and survive. Of the many tools that it provides to Member States, we recall European structural and investment funds. These have proved to be important for the EU accession process, being a consistent motivation for Member States. For Romania, European funds are an instrument able to ensure the structural reorientation of the economy, as the model practiced by Romania proved to be outdated by the current economic and social realities. Moving from a low-cost and low-added-value economic model to a model based on innovation and high added value is an approach that can be funded and implemented through European structural and investment funds. The importance of these funds for Romania is significant, the analysis of the absorption process being considered a matter of maximum importance for the stakeholders of the economic and social environment. 


\section{Literature review}

In a European Union that heterogeneously integrates economic and social differences, differences caused by an uneven distribution of economic activities that are reflected in the quality of life, (Tvrdon, 2012), the need to build confidence in the future of the European project is acute. Against a tense Europe, clearly shaken by the economic crisis and by the global geopolitical situation, the European Commission is launching the Europe 2020 strategy. It was launched in 2012 as a successor to the Lisbon strategy to generate smart, sustainable and inclusive growth in European Union (Bilas, 2015). Cantillon (2011) analyzed the effects of the Lisbon Strategy on growth and social inclusion. The results of the analysis showed that the Lisbon strategy did not contribute to poverty reduction but, on the contrary, it stagnated or even rose. This situation is generated by the increase in employment rates that brought minor benefits to households where nobody works, so the number of households where more people worked increased and the number of nobody working remained unchanged. (Cantillon, 2011) The failure of the Lisbon Strategy is also caused by a number of overly ambitious targets, an insufficient number of institutions responsible for economic policy, poor governance and poor coordination between Member States (Natali, 2010; Tausch and Heshamti, 2010; Ruta, 2009). In 2010, Sarcinelli considered that the Lisbon strategy was a failure also due to the lack of an adequate monitoring and performance assessment system, based on clear and objective indicators. The Europe 2020 strategy maintains these strategic flaws inherent in its architecture (Sarcinelli, 2010) Pereira considers that all the results of the implementation of the Lisbon Strategy have been eradicated by the economic crisis, which has a considerable influence on the implementation of the Europe 2020 Strategy. (Pereira, 2011) Stahl and Spinaci (2010) have succeeded in involving the whole range of actors interested in its implementation, especially local and regional public authorities. (Stahl and Spinaci, 2010) Other specialists believe that Lisbon failure is due to the limits of the competence of the European Commission in relation to the Member States. One of the biggest obstacles to the implementation of supranational strategies is that most of the objectives of these strategies are not within the competence of the European Union. The Lisbon Strategy is categorized by a significant number of specialists as a failure. It failed to meet its targets amid a very flexible programming period, which was affected by a series of economic crises. Confidence in the capacity of European funds to generate development has been strongly shaken during the 2007-2013 programming period.

The transition from the Lisbon Strategy to Europe 2020 was achieved under the influence of a series of crises affecting the economy. In a context where the confidence in the European project is deeply shaken and economic pessimism reaches high levels, a large number of experts agreed that the Europe 2020 strategy should involve more realistic objectives, in line with the future growth prospects of the EU and the main objectives of the strategy (Codogno et al., 2009, Fischer et al., 2010). The differences between the Lisbon Strategy and Europe 2020 are based on imperative elements needed for a coherent growth of the European economy and to reduce territorial disparities. The flexibility, the thematic focus of the interventions and the increased control of the Member States represent the pillars of the 2014-2020 programming period. The context of adopting the Europe 2020 strategy is extremely delicate. The number of euro-skeptics has grown significantly due to the economic crisis and this has resulted in a referendum for Brexit. The crisis has greatly highlighted the structural weaknesses of the European economy and, last but not least, has brought nationalism back to the public agenda. It had an economic connotation immediately after the crisis, and then it would also get social connotations. The considerable differences between the West and the East have made any European strategy or initiative a considerable dose of unevenness. Differences between Member States in market management systems, R \& D systems up to differences in the establishment of a company are weak points in any strategic approach. To these are added variables fund facing all world economies such as the aging population, the fourth industrial revolution, environmental issues, increasing global population, lack of sustainability of pension systems (Höpker, 2013) but also a financial system that tends to become overregulated. The strength and intensity of the negative impact of the global financial crisis has highlighted a number of shortcomings and structural problems that the European economy will have to address (Čajka et al., 2014). It is more than clear that the European Union has to face a series of increasing challenges both in the economic and political spheres. The influence of globalization on the growing interdependence between geo-economic units, not only at regional and global level, is significant (Terem et al., 2015). The economic crisis has created a number of obstacles to 
economic growth, which has the effect of reducing social benefits and public services in the European Union, generating a crisis and de-legitimizing the welfare state (Johnson, 1987; Navarro, 2011).

The Europe 2020 strategy is much more specific, integrating 5 thematic objectives and a set of quantitative targets tailored to the context of each Member State. The 5 objectives have as their primary objective to realize from the economy of Europe an economy whose growth is smart, sustainable and inclusive. Smart growth requires knowledge and innovation based development, sustainable growth requires a green growth based on resource efficiency and economic competitiveness and inclusive growth is aimed at promoting employment, social and territorial cohesion (European Commission, 2010a). Although the 3 growth characteristics desired by the EU are interdependent (smart, sustainable, inclusive), they are both antagonistic at the same time. The objectives proposed by the European Commission are representative and interconnected but the approach at Member State level will be different as there are considerable differences in development. These objectives are translated into national targets in line with the situation of each Member State (Isac et al., 2013).

The Europe 2020 Strategy mentions the internet as a catalyst for achieving the goals set in the strategy. For more coherence and for easy monitoring of the implementation process, a series of flagship initiatives have been derived from the Europe 2020 strategy. The reason for adopting these types of instruments is that they address the most important economic and social needs of the European Union. The flagship initiatives referred to are the following:

- An Innovation Union;

- Youth on the Move;

- A Digital Agenda for Europe;

- A Resource Efficient Europe;

- An industrial policy geared to the globalization era;

- An Agenda for New Skills and New Jobs;

- A European Platform for Combating Poverty.

The air of skepticism generated by the failure of the Lisbon strategy has also been transferred to Europe 2020. Pereira believes that the Europe 2020 strategy gives little attention to the global economic and political context and is more focused on internal affairs. Deregulation of international markets and financial sectors are considered to be the main elements responsible for the global financial crisis. Europe 2020 does not pay attention to these markets or these sectors (Pereira, 2011). Gros and Roth (2012) analyzed whether the 5 objectives of the Europe 2020 strategy will contribute to increasing the competitiveness of Member States' economies. The results of this analysis have shown that certain objectives cannot be assessed due to differences in their definitions at Member State level and, due to this situation, the success of the Europe 2020 strategy is questionable (Gros and Roth, 2012). Theodoropoulou and Watt (2011) notes that there is a strong likelihood that Member States will adjust their fiscal policies used during the economic crisis with measures needed to achieve smart, sustainable and inclusive growth, on public investment and education spending. They raise doubts as to the achievement of poverty targets, objectives that are found within Europe 2020 (Theodoropoulou and Watt, 2011). Without economic growth, it is impossible to counteract the crisis in labor market. Ruiz believes that the current economic crisis has aggravated inequalities between regions, but none of the Europe 2020 goals is about reducing inequalities. This is considered to be one of the major shortcomings of the Europe 2020 strategy, referring here to the fact that social cohesion has been left aside (Ruiz et al., 2013). In order to be sustainable and at both political and administrative level, the Europe 2020 objectives must take into account the principle of good governance. Otherwise, Europe 2020 can have the same fate as the Lisbon strategy (Marek, 2016).

\section{Methodology of research and data. Results and discussions}

The 2014-2020 programming period is deeply different from the previous programming period. The performance framework, the Partnership Agreement and a level of flexibility are elements specific to the 2014-2020 programming period. Thematic concentration is one of the most innovative elements integrated within a programming period so far. In order to achieve the thematic concentration between existing needs and existing funding, the 2014-2020 programming period integrates a new instrument, namely thematic objectives. They are set up at European level, with each Member State being free to choose how many 
thematic objectives address in the light of the specificity of economic and social relations. Thematic objectives are an element of greatest importance at the level of the programming period, providing a thematic concentration of investments. One of the main meeting deficiencies in the previous programming period, namely the lack of a link between needs and European funds, is virtually canceled. Although there is a possibility to use a smaller number of thematic objectives, Romania has chosen to use for the 2014-2020 period all 11 thematic objectives available, these being the following:

1. Strengthening research, technological development and innovation;

2. Improve access to information and communication technology, use and its quality;

3. Improve the competitiveness of SMEs, the agricultural sector and the sector fisheries and aquaculture;

4. Support the transition to a low-carbon economy in all sectors;

5. Promoting adaptation to climate change, prevention and risk management;

6. Preserving and protecting the environment and promoting the efficient use of resources;

7. Promote sustainable transport and eliminate bottlenecks in major network infrastructures;

8. Promote sustainable and quality employment and support for labor mobility;

9. Promoting social inclusion, combating poverty and any form of discrimination;

10.Investments in education, training and training for skills development and lifelong learning;

11.Increasing the institutional capacity of public authorities and stakeholders and efficient public administration.

Table 1.Distribution of thematic objectives by operational programs

\begin{tabular}{|l|r|c|c|c|c|c|c|c|c|c|c|c|}
\hline $\begin{array}{c}\text { Operational } \\
\text { program }\end{array}$ & $\begin{array}{c}\text { Budget allocation } \\
\text { Thousand euro }\end{array}$ & $\begin{array}{c}\text { TO } \\
\mathbf{1}\end{array}$ & $\begin{array}{c}\text { TO } \\
\mathbf{2}\end{array}$ & $\begin{array}{c}\text { TO } \\
\mathbf{3}\end{array}$ & $\begin{array}{c}\text { TO } \\
\mathbf{4}\end{array}$ & $\begin{array}{c}\text { TO } \\
\mathbf{5}\end{array}$ & $\begin{array}{c}\text { TO } \\
\mathbf{6}\end{array}$ & $\begin{array}{c}\text { TO } \\
\mathbf{7}\end{array}$ & $\begin{array}{c}\text { TO } \\
\mathbf{8}\end{array}$ & $\begin{array}{c}\text { TO } \\
\mathbf{9}\end{array}$ & $\begin{array}{c}\text { TO } \\
\mathbf{1 0}\end{array}$ & $\begin{array}{c}\text { TO } \\
\mathbf{1 1}\end{array}$ \\
\hline HCOP & $4.326,84$ & & & & & & & & $\mathrm{x}$ & $\mathrm{x}$ & $\mathrm{x}$ & \\
\hline OPC & $1.329,78$ & $\mathrm{x}$ & $\mathrm{x}$ & & & & & & & & & \\
\hline LIOP & $9.418,53$ & & & & $\mathrm{x}$ & $\mathrm{x}$ & $\mathrm{x}$ & $\mathrm{x}$ & & & & \\
\hline ROP & $6.700,00$ & $\mathrm{x}$ & & $\mathrm{x}$ & $\mathrm{x}$ & & $\mathrm{x}$ & $\mathrm{x}$ & $\mathrm{x}$ & $\mathrm{x}$ & $\mathrm{x}$ & $\mathrm{x}$ \\
\hline OCBP & 553,19 & & & & & & & & & & & $\mathrm{x}$ \\
\hline NPRD & $8.127,99$ & $\mathrm{x}$ & & $\mathrm{x}$ & $\mathrm{x}$ & $\mathrm{x}$ & $\mathrm{x}$ & & $\mathrm{x}$ & $\mathrm{x}$ & & \\
\hline OPMAF & 168,42 & & & $\mathrm{x}$ & $\mathrm{x}$ & & $\mathrm{x}$ & & $\mathrm{x}$ & & & \\
\hline
\end{tabular}

Source: Operational Programs 2014-2020/Ministry of European Funds

Thematic objectives are a link between the 2014-2020 Partnership Agreement 2014 - 2020 and the operational programs. The more complex an operational program is, the more it integrates a larger number of specific objectives. The table above illustrates both Romania's allocations for 2014-2020 and the number of thematic objectives found at the level of the operational program. The Human Capital Operational Program is a program that targets a major need for Romania's social dynamics, namely the labor market, education and poverty reduction. It integrates 3 thematic objectives and its allocation is 4,326.84 thousand euro. Another program is the Operational Program for Competitiveness, which integrates 2 thematic objectives and benefits from an allocation of 1,329.78 thousand euro. The Operational Infrastructure Program is one of the most important programs because it addresses one of Romania's most important needs at the economic and social level, namely infrastructure. It benefited from the allocation of 9,418.53 thousand euro and the program integrates 4 thematic objectives. Another program of similar importance is the Regional Operational Program, which integrates the majority of the existing thematic objectives, 9 in number, and benefits from an allocation of 6,700 thousand euro. The Operational Program for Administrative Capacity Building, a program aimed at the development of public administration in support of economic growth, corresponds to a single thematic objective and benefits from an allocation of 553.19 thousand euro. All of the above mentioned projects correspond to the Cohesion Policy 2014-2020, which derive from it. The Common Agricultural Policy integrates two operational programs. The program considers it to be representative is the National Program for Rural Development, which mainly concerns the development of the rural space. The program benefits from an allocation of 8,127.99 thousand euro and integrates 7 thematic objectives. Also, the Operational Program for Maritime Affairs and Fisheries benefits from an allocation of 168.42 thousand euro and integrates 4 thematic objectives. 
Analysis of exposure of thematic objectives on operational programs is an important variable for the absorption analysis. The analysis of these variables has shown that the Regional Operational Program and the National Rural Development Program are the programs that benefit from most of the thematic objectives, which finance most needs in the 2014-2020 programming period. From the allocation point of view, we can see that all these programs benefit from significant financial allocation. However, the Large Infrastructure Operational Program benefits from the highest allocation in the 2014-2020 programming period. The existence of the amounts available to finance economic and social development does not necessarily represent the existence of absorption. This depends on a number of factors that concern the management of operational programs, stakeholder involvement, and the relationship between project beneficiaries and funding guidelines.

\section{Dynamics of absorption of European structural and investment funds in the 2014-2020 programming period in Romania}

Romania is currently involved in managing the second programming period since it became a member state. The first programming period in which Romania was involved should be considered as one of accommodation, representing the first direct contact with the European structural and investment funds system. Romania's experience in generating absorption in the programming period 2007-2013 can be considered as one in the European average, with the overall absorption registered by Romania being about $80 \%$. It should be noted that this absorption rate was achieved with a series of concessions from the European Commission. Taking into account the acquired experience, the implementation capacities achieved, it is assumed that the next programming period will generate significant improvements in the absorption. Besides the political need to generate absorption, there is also the investment need that the Romanian economic and social environment needs. Absorption analysis integrates two important parameters to characterize the absorption dynamics, namely payments made to beneficiaries and reimbursements from the European Commission.

Table 2. Absorption under the Regional Operational Program

\begin{tabular}{|c|c|c|c|c|c|}
\hline \multirow{2}{*}{$\begin{array}{c}\text { Operational } \\
\text { program }\end{array}$} & Reporting date & \multicolumn{2}{|c|}{$\begin{array}{c}\text { Payments to beneficiaries (EU) - } \\
\text { euro }\end{array}$} & \multicolumn{2}{c|}{$\begin{array}{c}\text { Reimbursements from the EC } \\
\text { (effective absorption rate) - euro }\end{array}$} \\
\cline { 3 - 6 } & & Value & \% & Value & $\%$ \\
\hline \multirow{2}{*}{$\begin{array}{c}\text { Regional } \\
\text { operational } \\
\text { program }\end{array}$} & 31.12 .2017 & 51.476 .744 & $0,78 \%$ & 24.272 .480 & $0,37 \%$ \\
\cline { 2 - 6 } & 30.03 .2018 & 78.072 .022 & $1,18 \%$ & 35.466 .577 & $0,54 \%$ \\
\cline { 2 - 6 } & 30.06 .2018 & 116.815 .057 & $1,73 \%$ & 65.095 .664 & $0,96 \%$ \\
\hline
\end{tabular}

Source: Ministry of European Funds

Analyzing the absorption situation under the Regional Operational Program, we can see that it is at very low rate. Although Romania started the programming period in 2014, we can observe that 3 years after the start of the programming period, payments to the beneficiaries were $0.78 \%(51,476,744$ euro) and on 30.06 .2018 it advanced to $1.73 \%(116,815,057$ euro). Reimbursements from the European Commission amounted to $24,272,480$ euro at $31.12 .2017(0.37 \%)$ and 65.095 .664 euro respectively on 30.06 .2018 $(0.96 \%)$. The absorption situation is one that demonstrates significant delays in program implementation. Also, the differences between payments made to beneficiaries and amounts reimbursed by the European Commission reinforce the idea that absorption will remain low, including in the future.

Table 3. Absorption under the Large Infrastructure Operational Program

\begin{tabular}{|c|c|c|c|c|c|}
\hline \multirow{2}{*}{$\begin{array}{l}\text { Operational } \\
\text { program }\end{array}$} & \multirow[t]{2}{*}{ Reporting date } & \multicolumn{2}{|c|}{$\begin{array}{c}\text { Payments to beneficiaries (EU) - } \\
\text { euro }\end{array}$} & \multicolumn{2}{|c|}{$\begin{array}{l}\text { Reimbursements from the EC } \\
\text { (effective absorption rate) - euro }\end{array}$} \\
\hline & & Value & $\%$ & Value & $\%$ \\
\hline \multirow{3}{*}{$\begin{array}{l}\text { Operational } \\
\text { Program for Large } \\
\text { Infrastructure }\end{array}$} & 31.12 .2017 & 968.827 .098 & $10,29 \%$ & 858.287 .778 & $9,11 \%$ \\
\hline & 30.03 .2018 & 1.042 .973 .832 & $11,07 \%$ & 953.653 .087 & $10,13 \%$ \\
\hline & 30.06 .2018 & 1.166 .342 .133 & $12,65 \%$ & 1.132 .265 .532 & $12,28 \%$ \\
\hline
\end{tabular}

Source: Ministry of European Funds 
The Operational Program for Large Infrastructure benefited from payments to beneficiaries of $968,827,098$ euro $(10.29 \%)$ at the end of 2017 , to reach $1,166,342,133$ euro (12.65\%) by the middle of 2018. Of these sums, an amount of $858,287,778$ euro (9.11\%) and $1,132,265,532$ euro (12.28\%) was reimbursed by the European Commission at the end of 2017 in the middle of 2018. We can see that absorption is one that did not generate financial corrections because the differences between paid and reimbursed amounts are low. We mention that a number of projects from the previous programming period have been taken over this program, generating absorption in the current programming period.

Table 4. Absorption under the Operational Program Competitiveness

\begin{tabular}{|c|c|c|c|c|c|}
\hline \multirow{2}{*}{$\begin{array}{l}\text { Operational } \\
\text { program }\end{array}$} & \multirow[t]{2}{*}{ Reporting date } & \multicolumn{2}{|c|}{$\begin{array}{c}\text { Payments to beneficiaries (EU) - } \\
\text { euro }\end{array}$} & \multicolumn{2}{|c|}{$\begin{array}{c}\text { Reimbursements from the EC } \\
\text { (effective absorption rate) - euro }\end{array}$} \\
\hline & & Value & $\%$ & Value & $\%$ \\
\hline \multirow{3}{*}{$\begin{array}{l}\text { Operational Program } \\
\text { Competitiveness }\end{array}$} & 31.12 .2017 & 146.572 .615 & $11,02 \%$ & 59.118 .754 & $4,45 \%$ \\
\hline & 30.03 .2018 & 176.478 .638 & $13,27 \%$ & 99.223 .367 & $7,46 \%$ \\
\hline & 30.06 .2018 & 206.646 .965 & $15,54 \%$ & 136.845 .990 & $10,29 \%$ \\
\hline
\end{tabular}

Source: Ministry of European Funds

The Operational Program Competitiveness situation is one that is considered to be in programspecific management parameters. At the end of 2017, sums that were paid to the beneficiaries amounting to $146,572,615$ euro (11.02\%) of which the Commission reimbursed $59,118,754$ euro (4.45\%). In the middle of $2018,206,646,965$ euro (15.54\%) were paid to beneficiaries, out of which $136,845,990$ euro (10.29\%) were reimbursed.

Table 5. Absorption under the Human Capital Operational Program

\begin{tabular}{|c|c|c|c|c|c|}
\hline \multirow{2}{*}{$\begin{array}{c}\text { Operational } \\
\text { program }\end{array}$} & \multirow{2}{*}{ Reporting date } & \multicolumn{2}{|c|}{$\begin{array}{c}\text { Payments to beneficiaries (EU) - } \\
\text { euro }\end{array}$} & \multicolumn{2}{|c|}{$\begin{array}{c}\text { Reimbursements from the EC } \\
\text { (effective absorption rate) - euro }\end{array}$} \\
\cline { 2 - 6 } & & Value & \% & \multicolumn{2}{c|}{ Value } \\
\hline \multirow{2}{*}{$\begin{array}{c}\text { PO Human } \\
\text { Resources }\end{array}$} & 31.12 .2017 & 25.014 .473 & $0,58 \%$ & 0 & $0,00 \%$ \\
\cline { 2 - 6 } & 30.03 .2018 & 60.455 .663 & $1,38 \%$ & 3.892 .197 & $0,09 \%$ \\
\cline { 2 - 6 } & 30.06 .2018 & 101.602 .857 & $2,32 \%$ & 20.081 .624 & $0,46 \%$ \\
\hline
\end{tabular}

Source: Ministry of European Funds

The Human Capital Operational Program records a low level of low absorption, as shown in Table 4. At 4 years from the start of the programming period, payments to the beneficiaries were only $0.58 \%$ $(25,014,473$ euro) of which have not been reimbursed by the European Commission. In mid-2018 payments to the beneficiaries were only $2.32 \%$ of the total allocation $(101,602,857$ euro), of which $0.46 \%(20,081,624$ euro) of the total allocation were reimbursed. Although the reduction of the labor deficit and poverty reduction are major objectives for Romania's economic and social environment, the concern of stakeholders interested in this operational program is a small one, proven by the level of absorption.

Table 6. Absorption within the Operational Program for Administrative Capacity

\begin{tabular}{|c|c|c|c|c|c|}
\hline \multirow{2}{*}{$\begin{array}{l}\text { Operational } \\
\text { program }\end{array}$} & \multirow[t]{2}{*}{ Reporting date } & \multicolumn{2}{|c|}{$\begin{array}{c}\text { Payments to beneficiaries (EU) - } \\
\text { euro }\end{array}$} & \multicolumn{2}{|c|}{$\begin{array}{l}\text { Reimbursements from the EC } \\
\text { (effective absorption rate) - euro }\end{array}$} \\
\hline & & Value & $\%$ & Value & $\%$ \\
\hline \multirow{3}{*}{$\begin{array}{c}\text { Operational } \\
\text { Program for } \\
\text { Administrative } \\
\text { Capacity }\end{array}$} & 31.12 .2017 & 24.709 .051 & $4,47 \%$ & 20.668 .383 & $3,74 \%$ \\
\hline & 30.03 .2018 & 31.369 .099 & $5,67 \%$ & 28.087.399 & $5,08 \%$ \\
\hline & 30.06 .2018 & 35.479 .256 & $6,41 \%$ & 31.324 .335 & $5,66 \%$ \\
\hline
\end{tabular}

Source: Ministry of European Funds

The consolidation of the public administration benefited from payments made to the beneficiaries amounting to 24.709 .051 euro $(4.47 \%)$ at the end of 2017 , of which 20.668 .383 euro (3.74\%) were reimbursed by the European Commission. In mid-2018, an amount of $35,479,256$ euro (6.41\%) was paid to 
the beneficiaries, of which an amount of $31,324,335$ euro $(5.66 \%)$ was reimbursed by the European Commission.

Table 7. Absorption under the National Operational Program for Rural Development

\begin{tabular}{|c|c|c|c|c|c|}
\hline \multirow{2}{*}{$\begin{array}{c}\text { Operational } \\
\text { program }\end{array}$} & Reporting date & \multicolumn{2}{|c|}{$\begin{array}{c}\text { Payments to beneficiaries (EU) - } \\
\text { euro }\end{array}$} & \multicolumn{2}{c|}{$\begin{array}{c}\text { Reimbursements from the EC } \\
\text { (effective absorption rate) - euro }\end{array}$} \\
\cline { 3 - 6 } & & Value & $\%$ & Value & $\%$ \\
\hline \multirow{2}{*}{$\begin{array}{c}\text { National Rural } \\
\text { Development } \\
\text { Program }\end{array}$} & 31.12 .2017 & 2.141 .031 .435 & $26,34 \%$ & 1.991 .025 .758 & $24,50 \%$ \\
\cline { 2 - 6 } & 30.03 .2018 & 2.742 .971 .899 & $33,75 \%$ & 2.397 .856 .059 & $29,50 \%$ \\
\cline { 2 - 6 } & 30.06 .2018 & 2.924 .288 .526 & $35,98 \%$ & 2.726 .129 .607 & $33,54 \%$ \\
\hline
\end{tabular}

Source: Ministry of European Funds

The development of the rural environment benefited by the end of 2017 payments amounting to $2,141,031,435$ euro representing $26.34 \%$ of the total allocation of which $1,991,025,758$ euro $(24,50 \%)$ were reimbursed by the European Commission. On 30 March 2018, sums of 2,742,971,899 euro (33.75\%) were paid out of which 2,397,856,059 euro (29.50\%) were reimbursed. Also, in the middle of 2018, $2,924,288,526$ euro (35.98\%) were paid to the beneficiaries, of which 2,726,129,607 euro (33.54\%) were reimbursed to the beneficiaries.

Table 8. Absorption under the National Operational Program for Rural Development

\begin{tabular}{|c|c|c|c|c|c|}
\hline \multirow{2}{*}{$\begin{array}{c}\text { Operational } \\
\text { program }\end{array}$} & \multirow{2}{*}{ Reporting date } & \multicolumn{2}{|c|}{$\begin{array}{c}\text { Payments to beneficiaries (EU) - } \\
\text { euro }\end{array}$} & \multicolumn{2}{c|}{$\begin{array}{c}\text { Reimbursements from the EC } \\
\text { (effective absorption rate) - euro }\end{array}$} \\
\cline { 3 - 6 } & & Value & \% & Value & \% \\
\hline \multirow{2}{*}{ POPAM } & 31.12 .2017 & 14.892 .225 & $8,84 \%$ & 9.785 .156 & $5,81 \%$ \\
\cline { 2 - 6 } & 30.03 .2018 & 19.928 .918 & $11,83 \%$ & 12.237 .475 & $7,27 \%$ \\
\cline { 2 - 6 } & 30.06 .2018 & 24.097 .049 & $14,31 \%$ & 19.425 .479 & $11,53 \%$ \\
\hline
\end{tabular}

Source: Ministry of European Funds

The fisheries sector benefited from investments in the form of payments from European funds of $14,892,225$ euro at the end of 2017. Of these, 9,785,156 euro was paid by the European Commission. In the middle of 2018, payments were made to the beneficiaries in the interest of the fisheries sector amounting to $24,097,049$ euro $(14.31 \%)$, of which $19,425,479$ euro $(11.53 \%)$ were reimbursed by the European Commission.

\section{Conclusions}

The failure of the Lisbon Strategy calls for a successful implementation of the Europe 2020 strategy by the Member States. The confidence in the European project is affected by the success of the Europe 2020 strategy and implicitly by a high rate of absorption of the European structural and investment funds. Analyzing the dynamics of the absorption of the European structural and investment funds registered by Romania, we can see that it differs from one operational program to another. The Regional Operational Program is one of the most complex operational programs if we observe its exposure on thematic objectives. This complexity has negatively affected absorption, this being the program with one of the lowest absorption rates. In a similar situation, there is the Human Capital Operational Program that although it does not benefit from a significant exposure to thematic objectives is a complex program against the needs that are tackles. The Large Infrastructure Operational Program has delivered an absorption that is considered decent, but this is a consequence of the previous programming period. The National Program for Rural Development is the program with the highest absorption rate, although the level of complexity is high. Rural development can be considered as one of the most funded needs for the programming period 2014-2020. Achieving a high level of EU funding at the end of the 2014-2020 programming period is a risky bet for some operational programs. The absorption rate at the level of the Regional Operational Program or the Human Capital Operational Program is extremely low, so it is necessary to recover the delays recorded so far. Observing the different dynamics from one operational program to another, it is necessary in the future to take an absorption analysis approach that takes into 
account the specificity of the operational program, the complexity of the need addressed or the level of involvement of stakeholders.

\section{References}

1. Čajka, P., Jaroszewicz, M., Strielkowski, W. (2014), Migration incentives and flows between Belarus, Moldova, Ukraine and the European Union: a forecasting model, Economics and Sociology, 2014, 7(4), 11-25.

2. Cantillon, B. (2011). The paradox of social investment state: growth, employment and poverty in the Lisbon era. Journal of European Social Policy, 21, pp.432-449.

3. Codogno, L., Odinet, G., \& Padrini, F. (2009). The use of targets in the Lisbon strategy. Economic focus, No. 14. Rome: Ministry of Economy and Finance.

4. European Commission (2010a). Europe 2020, A strategy for smart, sustainable and inclusive growth. Brussels: Communication from the Commission.

5. Fischer, S., Stefan, G. et al. (2010). Europe 2020: Proposals for the post-Lisbon strategy. International policy analysis. Berlin: Friedrich Ebert Stiftung.

6. Gros, D., Roth, F. (2012). The Europe 2020 Strategy: Can It Maintain the EU's Competitiveness in the World? Brussels: Centre for European Policy Studies.

7. Höpker, L. (2013). The Chances of Success of the Europe 2020 Strategy - An Analysis against the Background of the Lisbon Strategy. Europa-Kolleg Hamburg Institute for European Integration, Study Paper No 4/13.

8. Isac, M.; Pavel, A.-P. (2013), Considerations regarding Romania's national objectives for the EU's growth strategy, Europe 2020. Calitatea, suppl. Supplement of Quality - Access to Success Journal: Acces la Success; Bucharest Vol. 14, Iss. 2, 109-113.

9. Johnson, N. (1987). The welfare state in transition. Brighton, UK: Wheatsheaf.

10. Natali, D. (2010). The Lisbon Strategy, Europe 2020 and the crisis in between. European Social Observatory . $4,1-26$.

11. Pereira, J. (2011). Europe 2020 - The European Strategy for Sustainable Growth, What Does It Look Like from Outside? Friedrich Ebert Stiftung, Dialogue on Globalization.

12. Ruiz Martos, M.J., Domínguez, A.S. (2013). Europe 2020 strategy: a strategy for which type of growth? Dpto. Teoría e Historia Económica Universidad de Granada, Working Paper n. 13/11.

13. Ruta, M. (2009). Why Lisbon fails? CESifo Economic Studies, 55(1), 145-164.

14. Sarcinelli, M. (2010). 'Europa 2020', Nuovo Governo Economico e Ri-Regolamentazione Finanziaria: Incentivi o Vincoli Alla Crescita? Moneta e Credito, 63(252), 285-319.

15. Stahl, G., Spinaci, G., (2010), Europe 2020: multi-level governance in action. U: European Policy Centre (2010) Europe 2020: Delivering Well-Being for Future Europeans, pp. 59-66.

16. Tausch, A., \& Heshamti, A. (2010), Learning from Latin America's experience: Europe's failure in the Lisbon process, Institute for the study of labor discussion paper series, No: 4779, Bonn: IZA.

17. Terem, P., Čajka, P., Rýsová, L. (2015). Europe 2020 Strategy: Evaluation, Implementation, and Prognoses for the Slovak Republic, Economics and Sociology, Vol. 8, No 2, pp. 154-171.

18. Theodoropoulou, S., Watt, A. (2011). Withdrawal symptoms: an assessment of the austerity packages in Europe. European Trade Union Institute, Working paper 2011.02.

19. Tvrdon, M. (2012). Cohesion Policy, Convergence and Regional Disparities: the Case of the European Union. WSEAS transactions on business and economics, 9 (2), pp. 89-99.

20. Vlatka, B. (2015). The Lisbon Strategy lessons: perspectives of the Europe 2020 implementation, 9th International Scientific Conference "Economic and Social Development", Istanbul, 9-10 April 2015. 